\title{
THE INFLUENCE OF COOPERATIVE LEARNING MODEL OF JIGSAW TYPE IMPLEMENTATION ON STUDENTS' LEARNING ACHIEVEMENTS
}

\author{
Iswan \\ Universitas Muhammadiyah Jakarta, South Jakarta, Indonesia \\ Corresponding author: iswanfipumj@gmail.com
}

\begin{abstract}
The research entitled "The Influence of Cooperative Learning Model of Jigsaw Type Implementation on Students' Learning Achievements" is aimed to find out the influences of Mathematics learning achievements in the subject of Fraction Numbers through the implementation of cooperative learning model of Jigsaw type at the $4^{\text {th }}$ graders of Public Primary school Wanasari 10 Cibitung Bekasi. Indonesia. The method used in this study was descriptive quantitative. Total number of the population was 94 students and the sample were chosen through simple random sampling in which 47 students were in the experimental class and the other 47 were in the controlled class. In analyzing the data, the indicator used was a test of learning achievements consisting of 20 questions with 4 options of answers. The findings of the research showed that the implementation of cooperative learning model of Jigsaw type influenced students' Mathematics achievements. The results of data analysis revealed that mean score gained by the students was 75 , while by using conventional method of learning, the mean score obtained was 58. Based on the statistical analysis of normality test, it was found that the value of $X^{2}$ cal $=-3105$ was lower than $X^{2}$ table $=11,07$ (with the
\end{abstract}


signifance level of $\alpha=0.05$ ) or showing normal distribution. While the statistical test analysis proved $t_{c a l}$ which was being synchronized with $t$-table, in which in significance level of $5 \%, \mathrm{dk}=\mathrm{n}-2=47-2=45, \mathrm{t}_{\text {table }}$ gained was 1.98 . Thus, it could be concluded that there was a difference of learning achievements reached by both experimental and controlled classes.

Keywords: The Implementation of Cooperative Learning Model, Jigsaw Type, Fraction Numbers Materials

\section{Introduction}

In general, the process of learning Mathematics at schools does not have good quality yet, especially in Indonesia. A good process must be quality-oriented and it is in line with the challenges of globalization in education which always demands various facets including the quality of graduates, competitive, so that it needs a better paradigm in mastering the variety of skills with based-technology learning process and applying high-critical thinking. One of the indicators used as the successful of learning Mathematics is in joining National-based Final Exam in Indonesia, in which for Mathematics itself, the lessons keep changing year by year. Therefore, the government of Indonesia always commits in determining the policy of qualified education. A plethora of problems should be handled wisely, these problems need to be solved especially by the components directly involved in the education world. Learning process of Mathematics is an abstract knowledge hence the concept of Mathematics lessons should also be presented in an abstract way. Due to different competence and ways of thoughts of the students in understanding and responding the subjects discussed in Mathematics taught in the class, it was found that some of the students are very slow. Mathematics taught at schools are generally related with the materials of numbering, symbols, and operational procedures used in solving problems regarding those numbers and symbols.

According to Soleh (1998:4), what expected in Mathematics education are that Mathematics is seen as a product (knowledge) and a process of model (activities), including in trying of making hypothesis, making symbols, creating models, finding patterns, interpreting, proving, generalizing, taking decision and delivering that decision. Further, Heruman (2008:1) explained, Mathematics is considered as a scary subject for some of the students since they thought that Mathematics is a very difficult lesson. Based on numerous problems above, in 
which most of the students are still having problems in understanding the concepts of Mathematics learning, the researchers are interested to investigate real conditions experienced by the $4^{\text {th }}$ graders of Public Primary School Wanasari 10 Cibitung Bekasi, Indonesia. Total numbers of the students being involved were 94 . The researchers found that one of the problems these students faced in learning Mathematics was the learning method which was less varied. In relation to this, this research study was ained to measure students' Mathematics learning achievements by applying cooperative learning model of Jigsaw type.

In Indonesia, students in the Primary level are in the ages between 6-12 years old. According to Piaget, at these ages, the students are in the phase of concrete opearational. It means the ability of thinking process to operate logic rules even they are still tied to concrete object. The mastery of the materials achieved by the students depends a lot on the teacher. The limited knowledge of a teacher is commonly problem found at schools. This is usually caused by one of many factors namely teachers who teach are not according to their fields. This makes the effectivity and totality of teaching and learning becomes less maximum. Teachers who do not have adequate knowledge will teach something not updated to the development of current science and technology. Since teachers are required to be able to deliver the materials to their students well, then they need to get knowledge about learning method and media can be used in that teaching and learning process. The main key to teacher success in teaching is in selecting appropriate strategy, model and method supported by teaching technique and tactics. Thus, the researchers tried to apply cooperative learning model of Jigsaw type.

\section{Formulation of the Problems}

Based on the background above, the problems of this study research were formulated as follows:

1. How did the application of Cooperative Learning Model of Jigsaw type in Fraction numbers learnt by $4^{\text {th }}$ graders of Public Primary School Wanasari 10 Cibitung Bekasi, Indonesia?

2. How did this Cooperative Learning Model of Jigsaw type improve those students' Mathematics of fraction numbers subejct's learning achievements?

3. How did this Cooperative Learning Model of Jigsaw type influence Mathematics learning achievements of $4^{\text {th }}$ graders of Public Primary School Wanasari 10 Cibitung Bekasi, Indonesia? 


\section{The Objective of the Research}

1. To find out and analyze the use of Cooperative Learning model of Jigsaw type on Mathematics subject of fraction numbers discussion at the $4^{\text {th }}$ graders of Public Primary school Wanasari 10 Cibitung Bekasi, Indonesia.

2. To find out and analyze the improvement of those students' Mathematics achievements of fraction numbers subject after being taught by using Cooperative Learning model of Jigsaw type.

3. To find out and analyze the influence of the implementation of Cooperative Learning model with Jigsaw type on those students' Mathematics achievements of fraction numbers.

\section{Research Design}

This research applied quantitative method with true experimental design, namely a type of good experiment which fullfils its requirement, and what refer to this requirement is the existance of another unidentified group that is being observed also (Arikunto:2010:125), with post-test only control design. In this design, there are two groups selected randomly (R). One group was given treatment $(\mathrm{X})$ while another one was not. The group which was being treated caleed experimental group and the one with no treatment was called controlled group. The influence of that treatment was $\left(\mathrm{O}_{1}: \mathrm{O}_{2}\right)$.

\section{Literature Review}

\section{The Definition of Learning Achievement}

Learning achievement is pattern of activity, value, understanding, attitude, appreciation and skill. Learning achievement is something that can be seen from two sides; from students' side and teachers' side. It is a level of a better mental development compared to the stages before learning (Dimiyati, 1999:250-251). Learning achievement is a learning ability shown in the changing of permanent performance providing facts, proofs, remarks, etc. While according to Sudjana (2012:45-46), learning achievement is the abilities possessed by the students after receiving their learning experiences. Based on several descriptions above, it can be assumed that learning achievement is something achieved through an effort to produce the development of better abilities than before the learning process. Learning achievements reached by the students are affected by two factors, i.e. from internal factor of the students themselves and from external factor or the factor of environment. 
The factor comes from the students themselves refers to the competence the students have. This competence gives a very big impact to the achievements the students are willing to reach. As Clark and Calvin Boy explained, students' achievements at school are 70\% influenced by those students' ability and the other $30 \%$ are affected by their environment. Learning achievement happens if someone has learned and then there is a changing in his/her behavious, such as from "do not know becomes know" and or from "do not understand becomes understand". Based on Bloom Taxonomy, learning achievement in a study can be achieved through 3 domains, namely: cognitive, i.e. intellectual learning achievement which consists of 6 aspects of knowledge covering knowledge, understanding, application, analysis, synthesis, and assessment.

The second domain is affective, a domain related with attitude and value. Affective domain covers every stage of receiving, answering or reaction, assessing organization and characterizing with a value of complex value. While the last domain is psycho-motor, which covers the motor skills, manipulating things, coordinating neuromuscular, connecting and observing. Type of cognitive learning achievement is the most dominant one compared to the affective and psycho-motor since it is more prominent, however, the results of learning of psycho-motor and affective are should be taken as parts of assessment in process of learning at schools. Learning achievement is a changing in an individual who does not only study about knowledge but also create skills and appreciation in the person him/herself who is studying (Nasution, 198:16). Based on several descriptions presented above, it can be assumed that learning achievement is something gained by someone after that person does an activity of learning which is not only realated with his/her intellectual ability but also the abilities of behaviours.

\section{The Definition of Mathematics}

Mathematics is a knowledge about the logic of shapes, formation, size, and other other interconnected concepts in huge numbers divided into three fields, namely algebra, analysis, and geometry. Mathematics is a science about numbers, the relation between numbers, and operational procedures used in solving the problems of nmbers. Mathematics, according to Ruseffendi, is a symbol of deductive science which does not take an inductively proof, a science of orderly patterns, and an organized structure starting from undefined element to axiom or postulate, and to rules. Several descriptions above can be assumed that Mathematics is a science which is related to other knowledge/sciences. 
The Facts of Mathematics, mathematics has a very broad defintions depending on the someones knowledge, understanding and experience, hence there are many experts who prove Mathematics from various point of views. Mathematics is a pattern of thoughts, a way of organizing a logic proof, it is a language, a language which uses terms defined carefully, clearly, accurately with solid symbols, more as a language of symbols of meanings than sound. While according to Reys, supported by Kiine, Mathematics can be defined as an analysis about patterns and connections of a way or way of thinking, an art, a language and a tool (Reys), thus, Mathematics is not an isolated subject, its existances help people in understanding and mastering social, economy, and nature matters (Kiine).

Based on those two opinions above, it can be assumed that Mathematics is a science discussed way of thinking, a structured knowledge which can be proven, a language expressed through symbols, and also an interconnected knowledge, cannot stand alone but assisting humans to understand problems in other sciences. Learning Mathematics is related to how applying it in taking decision to overcome problems. Mathematics involves observation, investigation, and its connection with both physical and social phenomenons (Schoenfield: 2009:130).

Referring to the curriculum of Mathematics, this subject functions as a place to: developing the ability to communicate with numbers and symbols, learning to sharpen logical thinking which can clarify and overcome problems in daily lives. While according to Soedjadi, in fact, Mathematics has an object of abstract goals, based on agreement and a deductive way of thinking. Based on that definition, it can be concluded that Mathematics does not only study numbers but also help humans to communicate through symbols and becomes the solution to solve problems in daily lives through reasoning and investigation.

\section{Cooperative Learning}

The Definition of Cooperative Learning. One of the practices of learning model which has been being accepted by many people for more than two decades is small group study of 'cooperative'. The interests toward this learning model keeps increasing day by day since schools have realized that there are more benefits both academically and socially gained by the students when they work together and help each other. The benefits from academic side includes; the ability to read and memorize vocabularies, writings, and etc. bekerjasama dan saling membantu satusama yang lainnya. Manfaat-manfaat akademik Besides, out of these academic merits, students' social skills also keep improved. Cooperatiove learning is a 
learning strategy with a number of students who have different competencies work in small groups. In accomplishing their tasks, every student as member of the group should work and assist one each other to understand the lessons. In this cooperative strategy, learning is not finish yet if one of friends in the group does not master the lessons yet. The students who are familiar working in groups will become more cooperative, helpful and reach higher academic achievements compared to the students who has never been familiar with this team-work model (Gilles dan Ashman:1996:266). Parker defined cooperative as a new learning atmosphere where the students interact one to another in small groups, to do academic tasks for the sake of achieving the goals. Art and Newman gave the definition of coopearative learning as small groups of learning or students who work in one group to solve a problem, accomplish an assignment, or reach the goals.

Cooperative learning model is not the same like other study-groups, it has basic elements which make it different from dividing groups randomly. Roger snd David Johnson said that not all group works can be said cooperative learning, thus, the elements of mutual cooperation must be applied (Roger dan David Johnson: 20034:31), covering:

Social inter-dependent, the success of a group's creation is mostly dependent on the effort of each group's member. In order to build an effective working-group, teachers need to design assignments in such a way so that every member of the group should accomplish his/her tasks by him/herself to achieve group purposes. Individul responsibility, if the tasks and assessment rubric made referring to the procedures of cooperative learning, each student will be responsible to do his/her best. Effective educators in cooperative learning model have good preparation and prepare the assignments well so that all individuals as the group members will do the tasks by themselves with fully responsible in order to do the next assignments of the group.

Face to face, in cooperative learning each group must be given opportunity to have face-toface session and have discussion. These interaction activities will provide the learners to form a synergy which will benefitted all mambers. The points of this synergy are appreciating diversity, taking advantages, and filling the gaps. Communication among members, this facet requires learners to be provided by various skills of communication, since the success of a group also depends on the willingness of every member to listen to each other and also the ability to express their opinions. Communication skills in a group is a long process. However, this process is very beneficial hence it is worth to be considered to enrich learning experiences and guide students' mental and emotional development. 
The evaluation of group process, educators need to design special schedule for the groups to evaluate both their working process and results so that in the next time, they can work more effectively. Some techniques that can be applied in cooperative learning are: Jigsaw, STAD, TGT Write Pair Square, Think Pair Square, Inside-Outside Circle, Round-Robin, NHT, Two Stay Two Stray, Group Investigation, Learning Together, Cooperative Controversy MurderMood, Understand, Recall, Detect, Elaborate, Review.

From the description above, it can be assumed that cooperative learning is one of learning models focusing on study group which has the aims to achieve learning achievements and improve students' ablility to socialize with other students.

\section{Cooperative Learning Types}

All methods in cooperative learning confirm ideas that students who work together in learning and be responsible with one another in their teams will be able to make themselves to learn together well. Three learning models which can be adapted to most of the subjects and grades are Student Team Achievement Division (STAD), Team Games Tournament (TGT), Jigsaw II. While the other two models are Cooperative Integrated Reading and Composition (CIRC) used in the process of learning reading at grade 2-8, and Team Accelerated Intruction (TAI) which is applied at Mathematics learning grade 3-6. These five methods involve appreciation, individuals' responsibilities, and chance of success, but with different efforts (Slavin, Robert: 2008:11).

The other models of coopearative learning which has been being developed beside those five aforementioned above are including Group Invesigation, Learning Together, Complex Intruction, and Structure Dyadic Methods. There are many more other models which may continue to increase since the researches on cooperative learning model are still on going and growing.

\section{Learning Steps}

\section{Cooperative Learning}

All types of Cooperative Learning above are basically have different steps, some might be similar, however, each of them has special steps or modifications according to its purposes. This is related to the characteristics and the materials that can be learnt. The followings are general steps of cooperative learning application (Slavin, 2008:25-26): selecting method, technique, and structure of appropriate cooperative learning that will be applied, setting the classrooms for cooperative learning, ranking the students individually based on their 
performances, determining numbers of groups, deciding groups, designing team building for each group, presenting the lessons, distributing students' working-sheets, assigning students to do quiz independently, assessing and scoring students' quizzes, giving appreciation to groups, evaluating groups' behaviours.

\section{The Merits of Cooperative Learning}

There are several basic elements which make cooperative learning become more productive than competitive and individual learnings, including: positive interdependency, each member of the groups must have the sense of being connected to other members so that they will feel fail if one member does not success in accomplishing his/her task. Promotive interaction is an interaction in groups in which every member supports and helps each other to reach group's goals. Individual accountability is aimed to make sure that the personalities of all group members can be strengthen through study groups. Interpersonal skills and small groups, the students must be taught social skills to work together effectively and to be motivated to apply those skills in groups so that productive conditions will be created. Processing groups, effective group works are commonly affected by how far those groups able to reflect their working processes.

\section{The Demerits of Cooperative Learning}

Slavin identified 3 main obstacles or what he called pitfalls, related to cooperative learning, namely: Free Rider: If it is very well designed, cooperative learning will give an impact to the existance of free rider. Free rider here refers to several students who are not responsible personally to their groups' assigments. Difussion of Responsibility is a condition where several members considered as not capable tend to be ignored by other members, those who are more capable. Learning a part of Task Specialization: In several certain methods, such as Jigsaw, Group Investigation, or other related models, each group is assigned to learn or do different parts of the subject discussion from one student to another. This type of assigning tasks often make students to focus on their parts only as their responsibility, while the other parts will hardly be out of their interest, eventhough those other parts of the materials are interrelated.

\section{Cooperative Learning of Jigsaw Type}

Jigsaw was firstly developed and tried-out by Elliot Aronson and friends at Texas University, and then being adapted by Slavin and his mates at John Hopkins University. Jigsaw teaching 
technique was developed by Aronson et.al. as a cooperative learning method. This technique can be used in teaching reading, writing, listening and or speaking. In this technique, teachers put their attention on studens' background of experiences, and help them to activate their schemata so that the learnings will be more meaningful. Beside that, the students will work together with other students in a communal work and have more chances to analyze the information and improve their communication skills. Cooperative learning of Jigsaw type is one type of cooperative learning consisted of some members in a group who are responsible for the masteri of the lessons and able to convey those materials to the other group members. In this Jigsaw technique, students work in group members who are determined previously, i.e. 4 persons, with different various backgrounds, these students are assigned to read the predetermined materials, small book or other materials. Each of group member is assigned randomly to become an "expert" in a certain aspect from that reading task.

As the example for instance, in a lesson unit about islands in Indonesia, one of the students in his/her groups is selected to become an expert of histoy, the other as the expert of economy, the third student as an expert of geography and the fourth as an expert of culture. After reading the materials, the experts from every different groups meet to discuss the topics that they are learning, and then they go back to their teacms to teach that topic discussion to their friends under the same teams. In the end, there is a quiz or other assessment types for all topics. The steps of cooperative learning of Jigswa type are; step 1, small groups, step 2, learning the same materials with the groups, step 3, the students get back to their groups, step 4, test (Isjoni:2009:56). From the descriptions above, it can be assumed that cooperative learning model of Jigsaw type is a model of learning aimed to improve well senses of responsibility and cooperation with groups.

\section{Fraction Numbers}

Fraction can be defined as part of something whole. In an illustration of a picture, that intended part is the one which needs to be paid attention to, and is being shaded. This part is called numerator. While the whole part is the one considered as a whole and it is called denominator. Centre for curriculum development and educational facilities of research and development explained that fraction is one of difficult topics to be taught. The difficulties can be seen from lack of meaningful learning activities carried out by teachers, and the difficulties of providing learning media. Intial concept of fraction is part of a whole (geometry concept). If a student loses this concept and is faced to calculation algorithms, then the success will be very difficult to be achieved. At all stages, giving adequate time to relate 
fractional to geometry. This way will give concrete experiences to bridge the gaps between abstract features stuck on numeric symbols (Sobex \& Maletsky, 2003:84).

Mathematics understanding is the ability to define, identify, make examples and nonexamples, use models, change a respresentative shape to other shapes, know various meanings and compare the characters of a concept. After these processes, the ideas will be appeared to make an example from a concept. Concept example can be interpreted with models, diagrams, and symbols. In the process of that understanding, Mathematics learning is needed to be adjusted with students' development, beside that students should be encouraged to be active in experiencing things which can help them to understand the concept of Mathematics, and then make those students skillful in their daily lives. The more active the students in learning Mathematics, the better their memories will be about Mathemtaics lesson. Cooperative learning method is a learning in which the students are given opportunities to work in small groups to accomplish or overcome a problem together. The students who study in a cooperative learning are supported to work cooperatively in doing tasks and they have to build coordination one and another to finish their assignments. Several components of cooperative learning of Jigsaw type, and the procedures to implement it are class presentation/teaching, study group/team, sharing tasks, discussion, back to the group, and then test. Presentation in the class is a presentation of the materials in the beginning of the learning. The students can be reminded to put their attention and understand that presentation because they should prepare for the discussion session.

In a group, there will be an interaction, class-mates, and cooperation. Students are split up to two small groups; home-group and expert group. Expert groups will discuss the materials delivered together and understand the discussions. And then one of the group members can go back to his/her home-group to explain the materials that he/she has discussed in the expert group. Beside that, each member of the groups has to understand the materials learnt since it will be used to discuss with other groups.

\section{The Findings of the Research}

Data Description, the description of the school as the research place, began with the establishment history of Public Primary School Wanasari 10 Cibitung, Bekasi, Indonesia. NSS:20218408, dan NPSN:101022207010, located at Bekasi Housing Complex, Regensi 2 
Block EE, in the village of Wanasari, Cibitung district, Bekasi regency, West Java province, Indonesia, as public school with the accredition "B". This school was established in 1991,

Table 2 Data of Teachers of Public Primary School Wanasari 10 Cibitung Bekasi, Indonesia Based on Departments

\begin{tabular}{|l|l|l|l|}
\hline No & Position & Frequency Absolute & $\%$ \\
\hline
\end{tabular}

belongs to government, with the wide of building $100 \mathrm{~m}^{2}$ and long: $200 \mathrm{~m}^{2}$. Geographically, the location of this school is very strategic, in the middle of residential neighborhood Bekasi regency. Students' Characteristics. General descriptions of $4^{\text {th }}$ grade students of Public Primary school Wanasari 10 Cibitung Bekasi, Indonesia, are focused on 2 instruments, namely: Total number of students based on gender and academic achievements. The reasons for taking these instruments because they are assumed influencing the success of learning process, especially the ones related to students' learning outcomes in the class as presented in the following table:

Table 1 The Data of Students of Public Primary School Wanasari 10 Cibitung Bekasi, Indonesia

\begin{tabular}{|c|c|c|c|c|c|}
\hline No. & Class & Boy & Girl & Total of the Class & $\begin{array}{c}\text { Total of the } \\
\text { Students }\end{array}$ \\
\hline 1 & I & 37 & 32 & 2 & $\mathbf{6 9}$ \\
\hline 2 & II & 45 & 40 & 3 & 104 \\
\hline 3 & III & 55 & 49 & 2 & 94 \\
\hline 4 & IV & 55 & 39 & 3 & 100 \\
\hline 5 & V & 61 & 39 & 2 & 58 \\
\hline 6 & VI & 30 & 283 & 14 & 510 \\
\hline
\end{tabular}

It can be seen from the table above that the students in the $4^{\text {th }}$ grade were 94 consisting of 55 boys and 39 girls, and this research was conducted on two classes of grade 4, i.e. IV A and IV B. Teachers' existance in the learning process is a significant instrument since they hold central position as the driver of teaching and learning process in the class. However, not all teachers run their teaching and learning process by applying appropriate models and methods yet to improve students' learning achievements. This school has qualified educators who are experts in their fields with professional educational qualifications as prescribed by Teacher and Lecturer Consitution. The following table below presents the data of the teachers at this school 


\begin{tabular}{|c|c|c|l|}
\hline 1 & Principal & 1 & 4.17 \\
\hline 2 & Class Teachers & 12 & 50 \\
\hline 3 & Subject Teachers & 9 & 37.5 \\
\hline 4 & Administration Head & 2 & 8.33 \\
\hline \multicolumn{2}{|c|}{ Total } & 24 & $100 \%$ \\
\hline
\end{tabular}

\section{The Results of Data Analysis}

Before collecting the data, the instrument used was firstly tested to get its validity and reliability. Based on the data obtained from the $4^{\text {th }}$ graders of Public Primary School Wanasari 10 Cibitung Bekasi, Indonesia, taken randomly, there were 20 students involved in this instrument test to calculate difficulty index, discrimination power, validity and reliability tests. The following Mathematics learning results used as the reference to determine which class would be used as experimental class and which one would be decided as control class:

Table $34^{\text {th }}$ Grade Students' Daily Scores of Mathematics of Fraction Numbers Subject

\begin{tabular}{|c|c|c|}
\hline Respondents & Scores of Class 4 B (Controlled) & Scores of Class 4 A (Experimental) \\
\hline R 2 & 70.3 & 52.7 \\
\hline R 3 & 69.7 & 70.3 \\
\hline R 4 & 53.3 & 75.7 \\
\hline R 5 & 67 & 58.3 \\
\hline R 6 & 68.3 & 49 \\
\hline R 7 & 64.7 & 51.3 \\
\hline R 8 & 66.3 & 68 \\
\hline R 9 & 64 & 64.7 \\
\hline R 10 & 63.3 & 64 \\
\hline R 11 & 68.3 & 50.3 \\
\hline R 12 & 68 & 69.7 \\
\hline R 13 & 77.7 & 60 \\
\hline R 14 & 67.7 & 72.3 \\
\hline R 15 & 65.3 & 65 \\
\hline R 16 & 70.3 & 77.3 \\
\hline
\end{tabular}




\begin{tabular}{|c|c|c|}
\hline R 17 & 71.3 & 48.7 \\
\hline R 18 & 70 & 64.7 \\
\hline R 19 & 63.7 & 58.7 \\
\hline R 20 & 69.3 & 64.7 \\
\hline R 21 & 64.3 & 70 \\
\hline R 22 & 62.3 & 68.7 \\
\hline R 23 & 74.7 & 73 \\
\hline R 24 & 61.7 & 55 \\
\hline R 25 & 57.3 & 55 \\
\hline R 26 & 55 & 51.7 \\
\hline R 27 & 66.3 & 62 \\
\hline R 28 & 73.7 & 63 \\
\hline R 29 & 76.7 & 62 \\
\hline R 30 & 68.7 & 72 \\
\hline R 31 & 66 & 48 \\
\hline R 32 & 68.3 & 55.7 \\
\hline R 33 & 65.7 & 60.3 \\
\hline R 34 & 58 & 48.7 \\
\hline R 35 & 59 & 70.3 \\
\hline R 36 & 61.3 & 62.3 \\
\hline R 37 & 64 & 68 \\
\hline R 38 & 66 & 64 \\
\hline R 39 & 71.7 & 60 \\
\hline R 40 & 73.3 & 59 \\
\hline R 41 & 70.7 & 69.3 \\
\hline R 42 & 65.7 & 73 \\
\hline R 43 & 51 & 48 \\
\hline R 44 & 64.3 & 64 \\
\hline R 45 & 68.3 & 49.3 \\
\hline R 46 & 69 & 63.7 \\
\hline R 47 & 74 & 66.7 \\
\hline
\end{tabular}


Based on daily scores for Mathematics of fraction numbers above, it can be seen that the average score gained by class 4 A was 61.9 and by class B was 66.3 , thus the class selected as experimental group was class 4 A while class B became the controlled group. Data of Students' Mathematics Outcomes, $4^{\text {th }}$ grade students' Mathematics learning outcomes between the class treated with Cooperative learning model of Jigsaw type and the class with no treatment of that model are described in the following table 4:

Table 4 Recapitulation of Students' Mathematics Learning Outcomes

\begin{tabular}{|c|c|c|c|}
\hline \multirow{2}{*}{ No } & \multirow{2}{*}{ Students' Codes } & \multicolumn{2}{|c|}{ Post Test } \\
\hline & & Control Group & Experimental Group \\
\hline 1 & K1 & 70 & 85 \\
\hline 2 & $\mathrm{~K} 2$ & 80 & 55 \\
\hline 3 & K3 & 80 & 55 \\
\hline 4 & K4 & 65 & 60 \\
\hline 5 & K5 & 80 & 60 \\
\hline 6 & K6 & 90 & 45 \\
\hline 7 & K7 & 80 & 40 \\
\hline 8 & K8 & 50 & 80 \\
\hline 9 & K9 & 75 & 60 \\
\hline 10 & K10 & 55 & 45 \\
\hline 11 & K11 & 90 & 70 \\
\hline 12 & K12 & 85 & 40 \\
\hline 13 & K13 & 75 & 70 \\
\hline 14 & K14 & 85 & 50 \\
\hline 15 & K15 & 85 & 65 \\
\hline 16 & K16 & 85 & 50 \\
\hline 17 & K17 & 90 & 55 \\
\hline 18 & K18 & 85 & 45 \\
\hline 19 & K19 & 65 & 60 \\
\hline 20 & K20 & 85 & 50 \\
\hline
\end{tabular}




\begin{tabular}{|c|c|c|c|}
\hline 21 & K21 & 65 & 65 \\
\hline 22 & K22 & 80 & 60 \\
\hline 23 & K23 & 80 & 75 \\
\hline 24 & K24 & 85 & 60 \\
\hline 25 & K25 & 80 & 60 \\
\hline 26 & K26 & 85 & 55 \\
\hline 27 & K27 & 80 & 70 \\
\hline 28 & K28 & 80 & 60 \\
\hline 29 & K29 & 75 & 55 \\
\hline 30 & K30 & 80 & 50 \\
\hline 31 & K31 & 85 & 55 \\
\hline 32 & K32 & 75 & 65 \\
\hline 33 & K33 & 65 & 40 \\
\hline 34 & K34 & 55 & 45 \\
\hline 35 & K35 & 60 & 65 \\
\hline 36 & K36 & 75 & 75 \\
\hline 37 & K37 & 80 & 70 \\
\hline 38 & K38 & 65 & 55 \\
\hline 39 & K39 & 85 & 60 \\
\hline 40 & K40 & 50 & 65 \\
\hline 41 & K41 & 50 & 75 \\
\hline 42 & K42 & 50 & 45 \\
\hline 43 & K43 & 55 & 40 \\
\hline 44 & K44 & 65 & 75 \\
\hline 45 & K45 & 80 & 70 \\
\hline 46 & K46 & 85 & 55 \\
\hline 47 & K47 & 75 & 45 \\
\hline \multicolumn{2}{|c|}{ Total } & 2750 & 3500 \\
\hline
\end{tabular}

Table 5

Recapitulation of Students' Mathematics Learning Outcomes of Experimental 
and Controlled Groups

\begin{tabular}{|c|c|}
\hline Group of Respondents & $\begin{array}{c}\text { Mathematics Learning } \\
\text { Outcomes }\end{array}$ \\
\hline & $\mathrm{N}=47$ \\
Experimental Class (Taught by & $\mathrm{F}=47$ \\
using Cooperative learning of & $\mathrm{Mx}=75.5$ \\
Jigsaw type) & $\mathrm{Me}=70.5$ \\
& $\mathrm{Mo}=96.5$ \\
\hline & $\mathrm{N}=47$ \\
Controlled Class (Taught & $\mathrm{F}=47$ \\
without using Cooperative & $\mathrm{Mx}=58.6$ \\
learning of Jigsaw type)) & $\mathrm{Me}=63.5$ \\
& $\mathrm{Mo}=50.15$ \\
\hline
\end{tabular}

The data of Experimental Groups's Mathematics Learning Outcomes with frequency distribution are presented in table 6 below:

Table 6 Frequency Table of Experimental Group's Post-test Scores

\begin{tabular}{|l|l|l|l|}
\hline No & SCORES & F & \% \\
\hline 1 & $85-91$ & 14 & 30 \\
\hline 2 & $78-84$ & 12 & 26 \\
\hline 3 & $71-77$ & 6 & 13 \\
\hline 4 & $64-70$ & 7 & 15 \\
\hline 5 & $57-63$ & 1 & 2 \\
\hline 6 & $50-56$ & 7 & 15 \\
\hline & Total & 47 & 85 \\
\hline
\end{tabular}

Based on frequency table above, it can be described that:

1) There were 7 students or $15 \%$ gained the scores between $50-56$

2) There was 1 student or 2\% under the scores between 57-63

3) There were 7 students or 15\% reached the scores between $64-70$

4) There were 6 students or 13\% hit the scores between $71-77$

5) There were 12 students or $26 \%$ with the scores between $78-84$ 
6) There were 14 students or $30 \%$ achieved the scores between $85-91$

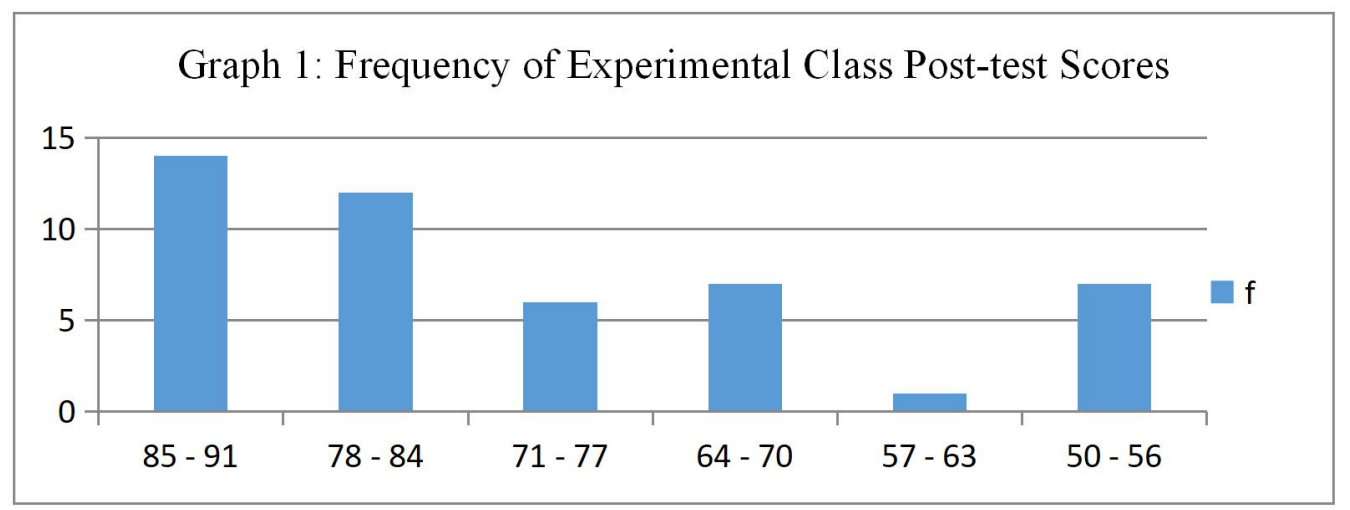

The comparison of Mathematics' learning outcomes average scores between. The graph of bar diagram above shows the differences of learning outcomes before and after the treatment of both experimental and controlled classes. In experimental class the average score of mathematics learning outcomes achieved 74.4, while controlled class reached 58.5. These results revealed that the average score obtained by experimental class was higher. The difference of the average scores of Mathematics learning was 15.9 or $7.5 \%$.

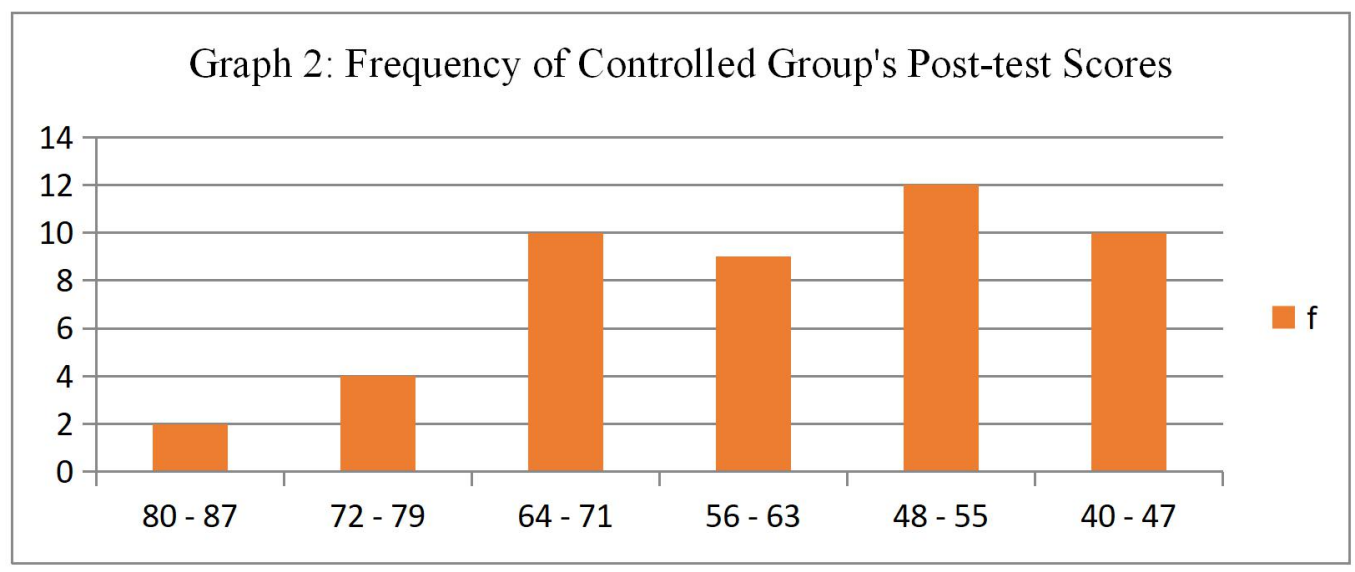

This difference appeared due to the process those two classes experienced. In experimental class, cooperative learning model of Jigsaw type was applied in which during the learning process the students studied in groups so that they became actively took roles in learning and in the controlled class, the students were taught using conventional method which applied lecturing and questions and answers session.

\section{Data Analysis of Instrument Trial}

Validity Test of Instrument's Trial, if $r_{\text {cal }}>r_{\text {table }}(0.196)$, the questions are confirmed as valid and if $\mathrm{r}_{\mathrm{cal}}<\mathrm{r}_{\text {table }}(0.96)$, then the questions are determined as invalid. The results found by the

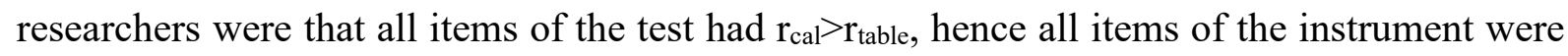
valid. 


\section{Normality Test}

In this research, the researchers used the formula of Chi Square to get the normality of the instrument's data. If the value of Chi Square table is lower $\left(X_{h}^{2}<X_{t}^{2}\right)$ then the distribution is categorized as normal, and vice versa, if Chi Square table is higher $\left(X_{h}<X_{t}^{2}\right)$, then the distribution is determined to be not normal.

Arranging data and finding the highest and the lowest scores

\begin{tabular}{|l|l|l|l|l|l|l|l|}
\hline No & SCORES & $\mathbf{f}$ & $\mathbf{\%}$ & $\mathbf{x}$ & $\mathbf{x 2}$ & $\mathbf{f x}$ & $\mathbf{f x 2}$ \\
\hline 1 & $85-91$ & 14 & 29.787 & 88 & 7744 & 1232 & 108416 \\
\hline 2 & $78-84$ & 12 & 25.532 & 81 & 6561 & 972 & 78732 \\
\hline 3 & $71-77$ & 6 & 12.766 & 74 & 5476 & 444 & 32856 \\
\hline 4 & $64-70$ & 7 & 14.894 & 67 & 4489 & 469 & 31423 \\
\hline 5 & $57-63$ & 1 & 2.1277 & 60 & 3600 & 60 & 3600 \\
\hline 6 & $50-56$ & 7 & 14.894 & 53 & 2809 & 371 & 19663 \\
\hline
\end{tabular}

\section{Determining Standard Deviation:}

$\mathrm{S}=\sqrt{\frac{(n \varepsilon f \times 2)-(\varepsilon f \mathrm{f}) 2}{n(n-1)}}$

$\mathrm{S}=\sqrt{\frac{(47.274690)-(3548) 2}{47(47-1)}}$

$\mathrm{S}=\sqrt{\frac{(12910430)-(12588304)}{2162}}$

$\mathrm{S}=\sqrt{148.9}=12.2$

Changing the score of $Z$ to normal curve area by using $0-Z$ table of normal curve

\begin{tabular}{|l|l|l|}
\hline & Z-score & Interval of Class Area \\
\hline $\mathbf{Z 1}$ & 0,74 & 27.03 \\
\hline $\mathbf{Z 2}$ & 0,17 & 06.75 \\
\hline $\mathbf{Z 3}$ & -0.4 & 15.54 \\
\hline $\mathbf{Z 4}$ & -0.97 & 33.40 \\
\hline $\mathbf{Z 5}$ & -1.54 & 43.82 \\
\hline
\end{tabular}




\section{Calculating data tabulation into class interval}

Class area of each interval

\begin{tabular}{|l|l|}
\hline $27,03-06,75$ & 20.28 \\
\hline $06.75-15.54$ & -8.79 \\
\hline $15.54-33.40$ & -17.86 \\
\hline $33.40-43.82$ & -10.42 \\
\hline $43.82-48.30$ & -4.48 \\
\hline
\end{tabular}

Calculating the score of $Z$ from each class limit with the following formula:

$$
\mathbf{Z}_{\mathbf{i}=\frac{\mathbf{X}_{\mathbf{i}}-\mathbf{X}}{\mathbf{S}}}
$$

$\mathbf{Z 1}=\frac{84.5-75.4}{12.2}=0.74$

$\mathbf{Z 2}=\frac{77.5-75.4}{12.2}=0.17$

$\mathbf{Z 3}=\frac{70.5-75.4}{12.2}=-0.40$

$\mathbf{Z 4}=\frac{63.5-75.4}{12.2}=-0.97$

$\mathbf{Z 5}=\frac{56.5-75.4}{12.2}=-1.54$

$\mathbf{Z 6}=\frac{49.5-75.4}{12.2}=-2.12$ 
ZScore Help Table

\begin{tabular}{|c|c|c|c|c|c|c|}
\hline Class Interval & Class Limit & Z-Score & $\begin{array}{l}\text { Width of } \\
0-Z\end{array}$ & $\begin{array}{l}\text { Outside } \\
\text { Interval }\end{array}$ & $\mathrm{Fe}$ & Fo \\
\hline \multirow[t]{2}{*}{$85-91$} & 84.5 & 0.74 & 27.03 & & 953.16 & 14 \\
\hline & & & & 20.28 & & \\
\hline \multirow[t]{2}{*}{$78-84$} & 77.5 & 0.17 & 06.75 & & -413.1 & 12 \\
\hline & & & & -8.79 & & \\
\hline \multirow[t]{2}{*}{$71-77$} & 70.5 & -0.40 & 15.54 & & -839.4 & 6 \\
\hline & & & & -17.86 & & \\
\hline \multirow[t]{2}{*}{$64-70$} & 63.5 & -0.97 & 33.40 & & -489.7 & 7 \\
\hline & & & & -10.42 & & \\
\hline \multirow[t]{2}{*}{$57-63$} & 56.5 & -1.54 & 43.82 & & -210.6 & 1 \\
\hline & & & & -4.48 & & \\
\hline $50-56$ & 49.5 & -2.12 & 48.30 & & & 7 \\
\hline
\end{tabular}

\section{Homogeneity}

Based on homogeneity test of $\mathrm{F}$ test in the significance level of 0.05 . The data used were the differences of average scores of post-tests gained by both experimental and controlled groups. The result of the calculations of those two variances, the population was homogenous or with $\mathrm{F}_{\text {cal }}<\mathrm{F}_{\text {table }}(1.103<1.632)$.

\begin{tabular}{|c|c|c|}
\hline \multicolumn{3}{|c|}{ F-Test Two-Sample for Variances } \\
\hline & Variable 1 & Variable 2 \\
\hline Mean & 74.46808511 & 58.5106383 \\
\hline Variance & 143.7326549 & 130.3422757 \\
\hline Observations & 47 & 47 \\
\hline $\mathrm{Df}$ & 46 & 46 \\
\hline $\mathrm{F}$ & 1.102732434 & \\
\hline $\mathrm{P}(\mathrm{F}<=\mathrm{f})$ one-tail & 0.37078943 & \\
\hline F Critical one-tail & 1.632463865 & \\
\hline
\end{tabular}




\section{The Analysis of t-test}

The hypothesis proposed in this study was "The application of Cooperative Learning Model of Jigsaw Type Gives Positive Effects to the $4^{\text {th }}$ Gaders' Mathematics Achievements". This hypothesis was tested by using te-test in the significance level of 0.05 with $n=47$ students in each class.

Significance Test of the Hypothesis

\begin{tabular}{|c|c|c|}
\hline \multicolumn{3}{|c|}{ t-test: two-sample assuming equal variances } \\
\hline & Variable 1 & Variable 2 \\
\hline Mean & 74.46808511 & 58.5106383 \\
\hline Variance & 143.7326549 & 130.3422757 \\
\hline Observations & 47 & 47 \\
\hline Pooled Variance & 137.0374653 & \\
\hline Hypothesized Mean Difference & 0 & \\
\hline $\mathrm{Df}$ & 92 & \\
\hline t Stat & 6.608116303 & \\
\hline $\mathrm{P}(\mathrm{T}<=\mathrm{t})$ one-tail & $1.24492 \mathrm{E}-09$ & \\
\hline t Critical one-tail & 1.661585397 & \\
\hline $\mathrm{P}(\mathrm{T}<=\mathrm{t})$ two-tail & $2.48984 \mathrm{E}-09$ & \\
\hline t Critical two-tail & 1.986086272 & \\
\hline
\end{tabular}

The result of $t_{\text {cal }}$ which was consulted to $t_{\text {table }}$ with signifance difference of $5 \%$ of two-tailed test of $\mathrm{dk}=\mathrm{n}-2=47-2=45$, was $1.98\left(\mathrm{t}_{\text {table }}=1.98\right)$.

\section{Interpretation}

Based on the results of the research and statistical analysis presented above, there were several interpretations as follows:

1. After the treatment, the mean score gained by class A (experimental class) was 75.5, this was higher than the mean score gained by controlled group (58). Thus, the final score of experimental class was bigger than the one obtained by controlled group. 
2. Based on validity test of the instrument, every single question had $r_{\text {cal }}>r_{\text {table }}$, therefore, it could be concluded that all questions were valid.

3. Based on reliability test, the instrument was valid and reliable used as the instrument in collecting data.

4. Based on normality test on the items of Mathematics learning achievements, it was found that the value of $X^{2}$ cal $=-3105$ was lower than $X_{\text {table }}^{2}=11.07$ with significant level of $\alpha=0.05$, which could be interpreted that it was normally distributed.

5. Based on homogeneity test using $F$ test in the significant level of 0.05 , the calculation gained from the data of different average scores of both experimental and controlled classes revealed that the two populations of those two variances were homogenous or similar to $\mathrm{F}_{\text {cal }}<\mathrm{F}_{\text {table }}(1.103<1.632)$.

6. Since the data of both groups (experimental and controlled) were normally distributed and homogenous, the next step of the test was comparing the average of the two populations by using $\mathrm{t}$-test. The test resulted $\mathrm{t}_{\mathrm{ca}}>\mathrm{t}_{\text {table }}$ in which $6.608>1.986$. This could be interpreted that there was significant influence of cooperative learning model of Jigsaw type on Mathematics achievements of $4^{\text {th }}$ grade students of Public Primary School of Wanasari 10 Cibitung Bekasi, Indonesia, for fractional numbers materials.

\section{Conclusions}

1. Based on the findings of the research, the average score gained by the students on Mathematics of fractional numbers subject taught by Cooperative learning model of Jigsaw type was 75 , while through conventional approach, the score was 58 in the average.

2. The students' Mathematics of fraction number subject achievements were improved through the implementation of Cooperative learning model of Jigsaw type during the teaching and learning process in which the mean score gained by the experimental group of students in the post-test was 74.4 while those in the controlled class obtained 58.5. These results revealed that higher average score of learning achievements were reached by the experimental group class. The differences of mean scores gained the two groups of the students hit the value of 15.9 or $7.5 \%$.

3. The implementation of Cooperative learning model of Jigsaw type gave positive effects to Mathematic achievements of the $4^{\text {th }}$ graders of Public Primary school Wanasari 10 Cibitung Bekasi, Indonesia, for fraction numbers lesson in which the students who learned by using Coopeartive learning model of Jigsaw type achieved the average score of 75 while 
those were taught through conventional method gained the average score of 58 . The result of $t_{\text {cal }}$ was converted to $t_{\text {table }}$ with the significance level of $5 \%$ of two-tailed test showed $d k=n-$ $2=47-2=45$, thus, it was gained $t_{\text {table }}=1.98$.

\section{Suggestions}

Based on the results of the research, there are several aspects that need to be considered and used by the researchers to propose the following suggestions:

1. The teachers are expected to apply Cooperative learning model of Jigsaw type in the process of learning at school since this model is appropriate and effective to be applied especially to Mathematics lesson since the learning process with this type of model focuses on student-centred, so that the students will be able to improve their activities, creativities, and also their learning achievements.

2. This type of learning model can be used as the solutions to the process of learning which is carried out as a routine, monotonous, and teacher-centred, hence it is expected that students will improve their learning achievements.

3. Teachers are also suggested to gradually update any type of conventional teaching method in the learning process to be more interactive, creative, and innovative so that the students will not be bored in receiving the lesson at school, and one of the ways is by applying Cooperative learning of Jigsaw type.

\section{REFERENCES}

[1] Arsyad, Azhar. (2007). Media Pembelajaran. Penerbit: PT. Raja Grafindo Persada. Jakarta. Indonesia.

[2] Braun. M. Coleman. C.S. Drew.D.A. (1983). Differential Equation Models, Modules in Applied Mathematic. Vol.1. Springer. New York. USA.

[3] Colak, E. (2012). The Effectiveof Cooperative Learning on The Learning Approaches of Students with Different Learning Styles, Eurasian Journal of Educational Research, 59 p. 17-34.

[4] Epstein. J.M. Axtell. R. (1997). Growing Artificial Societies. MIT. Press. Cambridge.

[5] Ganie, Tajuddin Noor. (2015). Buku Induk Bahasa Indonesia: Pantun, Puisi, Syair, Peribahasa, Gurindam dan Majas. Penerbit: Askara. Yogyakarta. Indonesia.

[6] Gaylord. R.J. D’Andria L.J. (1998). Simulating Society- a Mathematica Toolkit for 
Modeling Sicioeconomic Behavior. Springer/Telos. Berlin.

[7] Helbing. D. (1995). Quantitative Sociodynamics Stochastic Merthods and Models of Social Interaction Processes. Dordrecht: Kluwer. Boston. London.

[8] Johnson, D.W. \& Johnson, R.T. (2007), An Overview of Cooperative Learning, http://www..co-operation.org/what-is-cooperative-learning.

[9] Kariadinata dkk. (2012). Dasar-dasar Statistik Pendidikan. Penerbit: Pustaka Setia. Bandung. Indonesia.

[10] Kasiram, Moh. (2008). Metodologi Penelitian. Penerbit: UIN Malang Press. Malang. Indonesia.

[11] Kurniawan, Heru. (2014). Pembelajaran Menulis Kreatif. Bandung: PT Remaja Rosdakarya. Indonesia.

[12] Munadi.Yudhi. (2013). Media Pembelajaran. Penerbit: REFERENSI (GP. Press Group). Jakarta. Indonesia.

[13] Nurgiyantoro. Burhan. (2005). Sastra Anak. Penerbit: Gadjah Mada University Press. Yogyakarta. Indonesia.

[14] ......(2010). Penilaian Pembelajaran Bahasa Berbasis Kompetensi. Penerbit: Gajah Mada University. Yogyakarta. Indonesia.

[15] Nurjamal, Daeng, dkk. (2011).Penuntun perkuliahan Bahasa Indonesia (Untuk Memandu Acara: MC-Moderator, Karya Tulis Akademik, dan Surat-menyurat). Penerbit: PT. Alfabeta. Bandung. Indonesia.

[16] O’Brennan, L. and Bradshaw. C. (2013). National Education Association Imfortance of School Climate https://www.nea.org/assets/docs/15584 Bully_free_Research_Brief4pg.pdf.

[17] Purba, Antilan. (2010). Sastra Indonesia Kontemporer. Penerbit: Graha Ilmu. Yogyakarta. Indonesia.

[18] Robert E. Slavin Allyn and Bacon. (1992). Research Methods in Education. Boston.

[19] Riduwan. (2013). Belajar Mudah Penelitian untuk Guru Karyawan dan Peneliti Pemula. Penerbit: PT. Alfabeta. Bandung. Indonesia.

[20] Slavin, R.E. (1989). Synthesis of Research on Cooperative Learning; www.ascd.org/ASCD/pdf/journals/ed_lead/el_198105_slavin.pdf.

[21] Sadiman, dkk. (2010). Media Pendidikan (Pengertian, Pengembangan dan Pemanfaatannya). Penerbit: PT. Rajagrafindo Persada. Jakarta. Indonesia.

[22] Semi, M. Atar. (2007). Dasar-dasar Keterampilan Menulis. Penerbit: PT.Angkasa. Bandung. Indonesia. 
[23] Sudjana. (2005). Metoda Statistika. Penerbit: PT. Tarsito. Bandung. Indonesia.

[24] Sugiyono. (2014). Metode Penelitian Pendidikan. Penerbit: PT.Alfabeta. Bandung. Indonesia.

[25] Sukardi, Edy. (2012). Pembelajaran Menulis. Penerbit: Uhamka Press.Jakarta. Indonesia.

[26] Sulyganistia, Trisma. (2013). Penerapan Layanan Informasi Karier Dengan Menggunakan Media Flashcard Untuk Meningkatkan Kemantapan Perencanaan Karier Siswa Kelas XI SMA Negeri 11 Surabaya. Jurnal BK UNESA 3(13):55-63.

[27] Sumiati, dkk. (2008. Metode Pembelajaran. Penerbit: CV. Wacana Prima.Bandung. Indonesia.

[28] Sundayana, Rostina. (2014). Statistika Penelitian Pendidikan. Penerbit: PT.Alfabeta. Bandung. Indonesia.

[29] Susilana, Rudi dan CepiRiyana. (2009). Media Pembelajaran. Penerbit: PT. Wacana Prima. Bandung. Indonesia.

[30] Suyanto, Kasihani K.E.(2007). English for Young Learners Melejitkan Anak Melalui English Class yang Fun, Asyik dan Menarik. Penerbit: Bumi Aksara.Jakarta. Indonesia.

[31] Tarigan, Henry Guntur. (2011). Dasar-dasar Psikosastra. Penerbit: PT. Angkasa. Bandung. Indonesia.

[32] ......(2008). Menulis Sebagai Suatu Keterampilan Berbahasa. Penerbit: PT. Angkasa. Bandung. Indonesia. 